\title{
Women Farmers' Access and Use of Land For Agriculture in Selected Communities of Anambra State, Nigeria
}

\author{
Enwelu, I. A. \\ Morah, U.L. \\ Dimelu, M. U. \\ Ezeano, C. I. \\ Department of Agricultural Extension, University of Nigeria, Nsukka, Nigeria
}

Doi:10.5901/mjss.2014.v5n26p37

\section{Abstract}

The study assessed women farmers' access and use of land for agriculture in Anambra State, Nigeria. A total of 80 women farmers were randomly selected for the study. Data were collected and analyzed using mean score, standard deviation and presented in percentage. The findings revealed that women perceived family inheritance (97.5\%) and communal inheritance $(92.5 \%)$ as land ownership structures existing in the communities. In case of women land ownership pattern, $98.8 \%$ of women own land in the name of their husbands. Women had high access to farm land for agricultural purposes such as individual land $(\bar{x}=2.90)$, family land $(\bar{x}=2.70)$ and communal land $(\bar{x}=2.28)$. But the conditions for women access to such farm land included: involvement of husband (98.8\%) and through male relative (86.2\%). Lands were used by women for backyard farming (98.8\%), poultry house (97.5\%) and vegetable production (92.5\%). Women farmers' constraints to access and use of land for agricultural purposes were: cultural barriers $(\bar{x}=2.94)$, present land ownership structure $(\bar{x}=2.89)$ and lack of collateral $(\bar{x}=2.52)$. Strategies to improve access and use of land by women included: promotion of women's participation in land matters $(\bar{x}=2.78)$ and economic empowerment of women $(\bar{x}=2.76)$. The study recommends that local government councils should grant land use rights to women to improve their access and use of land for agricultural purposes.

Keywords: Women farmers, access and use, land, agricultural production and Anambra State

\section{Introduction}

The basis of agricultural production and the most important production factor for farmers is land. It has essential role to play in increasing as well as sustaining agricultural productivity. It is also a very important instrument in any economic manipulation which makes it important for speculations. In traditional agriculture, more land also means more income and better life. According to British Council Nigeria (2012), an estimated 54 million of Nigeria's 78 million women are based in rural areas and make a living from the land.

Broadly speaking, the idea of women as productive partners in agriculture and various roles played by women as farmers, farmwives and agricultural professionals are not in doubt. Recounting the stories of successful women in these roles in many cultures, women are the farmers on whom families and communities depend for food production. They engage in farm land activities as a means of sustaining the family.

Women are veritable tools in the development of any economy. According to Ekesionye and Okolo (2012), modern day Nigerian women take part in important economic activities for the benefit of their families and the entire nation. The researchers state that in rural areas, women participate fully in food production, processing and distribution which they combine with their traditional role of child bearing and procreation and home management. In performing these activities, women require enabling environment and resources to operate at maximum potential. One of such resources required by women is land. Access to land implies fair distribution, sustained utilization and development of the economy.

Land supplies both food and a place to live in. Without land, no human being can exist on the surface of the earth. Even in prehistoric times, people relied upon access to land as hunters, and even the animals they hunted required a lot of space to survive

In Anambra state, rural women access and use of land is fundamental in alleviating the poverty in rural areas because rural women are actively engaged in land based economic activities such as farming, housing, landscaping etc. 
Women tend to spend considerable part of their cash income on household food requirements. The contribution of women to the survival of the family is often as high as the husbands although this may not always be possible to count in monetary aspect. Women invest energy and resources in their houses but this can be difficult to estimate. Women can make better use of land if they have some sort of guaranteed right because that would help and encourage them to make the right long and short term input and management decisions toward achieving better result.

But it is surprising that although women represent between $60 \%$ and $79 \%$ of Nigeria's rural labour force, men are five times more likely to own land than women (British council Nigeria, 2012). Also, Aluko and Amidu (2006) reported that women's rights of access are still regarded as secondary to those of men, and many customs suggest that women's access to land is still mediated via patriarchal systems in spite of the 1978 Land Use Act that nationalised all land and vested authority in the State Governor who holds it in trust on behalf of all. Their access to land is severely curtailed by the way land is inherited, owned and passed on by men to their male descendents in most patriarchal ethnic groups especially in southern Nigeria including Anambra state.

On the other hand, one thing is to have access to land another thing is to use it. However, it is assumed that lack of unfettered access to land by women may affect their ability to use the land. For instance, to secure loan from the formal sector like banks, it requires land as collateral which women may not have ownership hence limiting their ability to use land for meaningful economic activities. Ikeduru (2002) affirmed that women find it difficult to get loan from the banks to undertake projects or businesses that would raise their income because they have no security (e.g. land) needed to secure such loan.

It is this marginalised position of women in Nigeria today in general and the Igbo race in particular that has attracted the attention of modern Scholars especially in arts, education and the sciences to speak against it in other to reverse the ugly trend (Ugwu, 2000). Also, there is increasing awareness nationally and internationally on the need to improve women access to means of production. For instance, strategic objective 55 of the Beijing platform of action calls for an increase in the productive capacity of women by providing "access to capital, resources, credit, land,..." Therefore, this study is an attempt to assess women access and use of land in rural communities of Anambra State.

On the basis of the forgoing, the study sought to: describe land ownership structure in Anambra State; determine women farmers' access to land for agricultural production; ascertain uses of land for agriculture by women farmers; determine constraints of women farmers to access and use of land for agriculture; and suggest strategies that can enhance women farmers' access and use of land for agriculture.

\section{Methodology}

The study was conducted in Anambra State. The state is made up of 21 local government areas with up to 700 communities (National Population Commission, 2006). There are three senatorial zones in the state namely: Anambra North, Anambra Central and Anambra South. Anambra people by nature are farmers, fishermen, craftsmen and traders. Among crops grown by farmers in the state are yam, palm produce, rice, cassava, cocoyam, vegetables, and different varieties of fruit trees among others.

The population of the study included all women farmers in Anambra state. A multi stage sampling technique was employed in selection of respondents. In the first stage, out of three Senatorial zones in the state comprising seven local government areas (LGAs) each, two zones were randomly selected. In the second stage, in each of the selected senatorial zone, two LGAs were randomly selected giving a total of four LGAs. In the third stage, town communities that make up each LGA were compiled and random selection of one town community from each LGA was made. In the fourth stage, a list of 20 women farmers was compiled in four village communities that make up each town community and 10 women farmers were randomly selected from the list compiled in each village community to give a total of 80 respondents for the study. Data were collected through the use of structured interview schedule and analyzed using mean score, standard deviation and presented in percentage.

Land ownership structure in selected communities of Anambra State was determined by listing different land ownership structures or patterns such as individual inheritance, communal inheritance, etc and requesting the respondents to indicate the ones existing in their communities. Also, women land ownership pattern was ascertained by asking the respondents to indicate the existing pattern from the list of patterns such as own land in husband's name, own land by purchase etc. The level of women farmers' access tofarm land wasdetermined by asking the respondents to rate their level of access on a three- point Likert-type scale of:high access (3), low access (2) and no access (1). Respondents with mean value equals to 2 or greater than 2 were regarded as having high access to farm land while those with mean value less than 2 were regarded as having low access to farm land. The condition for women access to land was obtained by asking the respondents to indicate such conditions like: involve husband, pay land rate etc. They were also 
asked to indicate their uses of land from the list of possible land uses. The extent of the constraints to access and use of land was measured on a three-point Likert-type scale of: to a great extent (3), to some extent (2) and to no extent (1). Effective strategies that can enhance women farmers' access and use of land for agricultural production were also measured on a three point Linkert type scale of very effective (3), effective (2) and not effective (1).

\section{Results and Discussion}

\subsection{Women Perception of Land Ownership Structures in the Communities}

Data in Table 1 reveal that women perceived family inheritance (97.5\%), communal inheritance (92.5\%), land lease $(90.0 \%)$, land purchase (88.8\%) and gift land (77.5\%) as land ownership structures existing in the communities.

The result implies that the four types of land ownership structures that exist in the communities may not permit women to own land and have unfettered access to it. According to Nwadiaro and Okoroafor (2011), a woman is expected to provide a letter of authorization from her husband before she can be allowed to purchase a piece of land in most traditional societies, and the same written permission is also required from her before she can obtain a loan from development banks. But it is only land ownership and land tenure that can give women security that can provide a key to access other resources and opportunities (British Council of Nigeria, 2012). For sustainable agriculture, access to all the four forms of land ownership structure is important in strengthening the human capital, social and financial capital which invariably can reduce poverty level of women. Therefore, the capacity of women to access these forms of land ownership structures will enable them to possess collaterals required to obtain credit from formal sector like banks.

Table 1: Women perception of land ownership structures in the communities

\begin{tabular}{lcc}
\hline Land ownership structures existing in the community & Frequency & Percentage \\
\hline Family inheritance & 78 & 97.5 \\
Communal inheritance & 74 & 92.5 \\
land lease & 72 & 90.0 \\
Land purchase & 71 & 88.8 \\
Gift & 62 & 77.5 \\
\hline
\end{tabular}

\subsection{Multiple responses}

\subsubsection{Women's Land Ownership Pattern}

Entries in Table 2 show that majority (98.8\%) of women own land in their husband's name. A negligible proportion of the respondents namely $3.8 \%, 3.8 \%, 3.1 \%$ and $1.2 \%$ reported that women own land in communities' name, in their fathers' name, by purchase and in Women Association's name respectively.

The implication of this finding is that women have no problem in land matters as long as they are happily married, but when their marriage is threatened; their ownership right may be withdrawn. Women's right to the husband's land is secure as long as the marriage lasts and unmarried women are not allowed to inherit landed property in patriarchal society like Anambra state even though they are actively involved in agricultural activities. This view was buttressed by British Council of Nigeria (2012) which reported that though many women are involved in subsistence agriculture and off farm activities, men are five times more likely than women to own land. In case of land purchase, women do not have enough capital to buy land which may be at the instance of the husbands or male relations even if the capital is available.

Table 2: Percentage distribution of women land ownership pattern

\begin{tabular}{lcc}
\hline Land ownership pattern & frequency & Percentage \\
\hline Purchase & 9 & 3.1 \\
In their husband's name & 79 & 98.8 \\
Community name & 3 & 3.8 \\
Father's name & 3 & 3.8 \\
Women association & 1 & 1.2 \\
\hline
\end{tabular}




\subsubsection{Level of Access of Women Farmers to farm Land for Agriculture}

Entries in Table 3 highlight level of access of women to different types of land in the communities. The results revealed that women had high access to purchased land $(\bar{x}=2.90)$ family land $(\bar{x}=2.70)$ communal land $(\bar{x}=2.28)$, gift land $(\bar{x}$ $=2.27)$ and land lease $(\bar{x}=2.19)$ but low access to land under custody $(\bar{x}=1.82)$.

The implication of this finding is that women generally have access to farm land in the communities for subsistence farming. However, through focus group discussion (FGD) it was found out that access to farm lands might not be a limiting production factor for women since certain conditions can be fulfilled to facilitate access to such lands. But control of such lands might be a major problem in terms of pledging them as collateral for a loan or even using them as they liked. Within the sphere of creating access to land, the finding is in line with Rahman (2004) who asserted that women in Nigeria form an active and reserve labor force but rarely own the means of production. According to British Council of Nigeria (2012), without land title, it is hard for women to raise the finance they need to start productive enterprise. However, women have access to land given to her as gift but may not be allowed to sell it and the land may be a small plot of land. This is in agreement with FAO (2013) which reported that $30.11 \%$ of women farmers in Nigeria were provided with a small plot of land by their husbands as gifts for their own productive activity.

Table 3: Mean distribution of level of access of women farmers to farm land for agricultural purposes

\begin{tabular}{lcc}
\hline & Mean $(\bar{x})$ & Std. Deviation \\
\hline Family land & 2.70 & 0.488 \\
Communal land & 2.28 & 0.527 \\
Land lease & 2.19 & 0.393 \\
Purchased land & 2.90 & 0.341 \\
Gift land & 2.27 & 0.826 \\
Land under custody & 1.82 & 0.497 \\
\hline
\end{tabular}

\subsection{Conditions for Women Access to Farm Land}

Table 4 highlight conditions of women access to land. The outstanding condition (98.8\%) is involvement of husbands. Other conditions include: purchase land (93.8\%), go through male relative (86.2\%), provide material things like, wine, kola etc $(67.5 \%)$ and pay land rate $(66.2 \%)$

The results of this finding imply that women access to farm land is based on fulfillment of certain conditions. Most of the conditions are beyond the capacity of an average woman. For instance, women do not have enough capital to purchase the land. This view is in agreement with World Bank (2009) report on the "Investment Climate in Nigeria" which shows that capital rather than productivity narrows the range of activities in which women engage. Also, Odurukwe et.al (2006) stated that women ranked such constraints as lack of access to land, lack of capital and credit facilities,.... as major hindrances to effective achievement of the Women in Agriculture set objectives of improving the socioeconomic wellbeing of women farmers.

The case of involving the husbands or going through male relatives is unsustainable and can jeopardize the chances of some women in securing land if they do not have husbands or have misunderstanding with their husbands or the male relatives. It is established fact that marriage has been the primary source of getting access to land under the customary system of tenure in sub-Saharan Africa. In Igbo customary law, in all areas of land holding, women are excluded as land passes from the father to the male children. Agricultural extension strategies traditionally have focused mainly in increasing the production of cash crops. Presently there is need for extension workers to explore synergy with other agencies involved in improving the productive capacity of women to include how they can own land in their educational programme.

Table 4: Conditions for women access to farm land

\begin{tabular}{lcc}
\hline Conditions of women access to land & Frequency & Percentage \\
\hline Involve husband & 79 & 98.8 \\
Pay land rate & 53 & 66.2 \\
Purchase land & 75 & 93.8 \\
Go through male relative & 69 & 86.2 \\
Provide material things (wine, kola etc) & 54 & 67.5 \\
\hline
\end{tabular}




\subsection{Various Uses of Land for Agriculture by Women Farmers}

Table 5 shows that majority (98.8\% )of the respondents used land for backyard farming while $97.5 \%, 97.5 \%, 92.5 \%$, $87.5 \%, 85.0 \%$ and $83.8 \%$ used land for poultry production, sheep and goat house, vegetable production, arable crops, tree crops and horticultural/ornamental plants respectively. Only few proportions of women use land for fish ponds (43.8\%) and piggery house (41.2\%). This result implies that the women generally make good use of available land that is accessible to them especially for backyard farming, poultry production, keeping of sheep and goat, crop production etc. This finding is in line with Ekesionye and Okolo (2012) who found that women were actively involved in economic activities in Anambra State e.g. farming (99.1\%) including livestock (53.3\%) and poultry (68.4\%).

Table 5: Percentage distribution of the various uses of land for agriculture by women farmers.

\begin{tabular}{lcc}
\hline Various uses of land for agriculture & Frequency & Percentage \\
\hline Arable crop production & 70 & 87.5 \\
Tree crops & 68 & 85.0 \\
Vegetable production & 74 & 92.5 \\
Horticulture/ ornamental plants & 67 & 83.8 \\
Backyard farming & 79 & 98.8 \\
Piggery house & 33 & 41.2 \\
Fish ponds & 35 & 43.8 \\
Poultry house & 78 & 97.5 \\
Sheep and goat house & 78 & 97.5 \\
\hline
\end{tabular}

\subsection{Perceived Constraints to Women Farmers' Access and Use of Land for Agriculture}

Data on Table 6 show the following perceived constraints to women farmers' access and use of land for agriculture: low extension contacts, $(\bar{x}=2.95)$, cultural barriers $(\bar{x}=2.94)$ present land ownership structure, $(\bar{x}=2.89)$, poor prices of agricultural goods ( $\bar{x}=2.87)$ lack of education, $(\bar{x}=2.62)$, lack of collateral $(\bar{x}=2.54)$, high level of poverty $(\bar{x}=2.44)$ and lack of suitable land $(\bar{x}=2.09)$.

The result evidently indicated that one of the major constraints to women farmers was low extension contacts. The finding is contrary to FAO (2013) report that majority of women farmers in Nigeria (58.12\%) rated extension workers as their primary source of advice for solving farming problems. On the other hand, cultural barriers and present land ownership structure adversely constrain women access and use of land for agricultural purposes. This view was stressed by Nwadiaro and Okoroafor (2011) when they reported that women are denied many of their fundamental rights (including access and use of land) for no other reason except that they are women. They are seen as incapable of having the rights their males counterparts have which consequently affects the roles assigned to them by the society. This is done in many ways such as through socialization process, role playing in the family, widowhood practices, family inheritance, culture and traditions of different rural communities.

Table 7: Perceived constraints to women farmers' access and use of land for agriculture

\begin{tabular}{lcc}
\hline Constraints & Mean $(\bar{x})$ & Std. Deviation \\
\hline Present land ownership structure & 2.89 & 0.318 \\
Cultural barriers & 2.94 & 0.244 \\
High level of poverty & 2.44 & 0.524 \\
Lack of collateral & 2.54 & 0.526 \\
Low education & 2.62 & 0.537 \\
Low extension contact & 2.95 & 0.271 \\
Lack of suitable land & 2.09 & 0.326 \\
Poor prices & 2.87 & 0.432 \\
\hline
\end{tabular}

\subsection{Perceived Strategies that can Enhance Women Farmer's Access and Use of Land for Agriculture}

Data on Table 8 show women's perceived strategies that can enhance their access and use of land for agriculture. The strategies perceived by the women to be effective in enhancing their access and use of land for agriculture included: 
more opportunity to women in all aspects of agriculture $(\mathrm{m}=2.89)$; abolition of certain cultures that debase women $(m=2.85)$; improving women's access to extension services $(m=2.84)$; promoting women's participation in bodies responsible for interpreting customary laws( $m=2.78)$; promoting adult education $(m=2.77)$; women empowerment $(m=2.76)$, introduction of modern farm inputs $(m=2.76)$; use of mass media to campaign for equality of women $(m=2.75)$; diversification of farming enterprise, $(m=2.75)$; government policy to address women access and use of land for agriculture $(m=2.73)$; use of women groups to state their case $(m=2.70)$; and involving women at each stage of the decision making process $(m=2.49)$.

The results reveal that all the listed strategies were effective in enhancing women farmers' access and use of land for agriculture. From these results, it is obvious that mere perception of effective strategies is not enough, but requires effective implementation of the strategies backed up with political will, advocacy and financial support. For instance abolition of certain cultures that debase women can easily be performed on paper but extremely difficult to implement in practical terms. This is similar to the assertion of British Council of Nigeria (2012), which states that in spite of the good intentions of the 1978 Land Use Act, the Nigeria land administration is largely egalitarian on paper. It requires further work to operationalize the act. Therefore, concerted efforts of all stakeholders are also needed to operationalize the perceived strategies so as to enhance women access and use of land in the communities.

Table 8: women's perceived strategies that can enhance their access and use of land for agriculture

\begin{tabular}{lcc}
\hline & Mean Std. Deviation \\
\hline Abolition of certain cultures & 2.85 & 0.361 \\
Women empowerment & 2.76 & 0.512 \\
Use of mass media & 2.75 & 0.518 \\
Government policy to address women's access and use of land & 2.73 & 0.524 \\
More opportunities to women in every aspect of agriculture & 2.89 & 0.392 \\
Use of women groups to state their case & 2.70 & 0.563 \\
Promoting adult education & 2.77 & 0.576 \\
Encouraging women to join cooperative societies for acquisition of loan. & 2.73 & 0.548 \\
Promoting women's participation & 2.78 & 0.523 \\
Improving women's access to ext services & 2.84 & 0.465 \\
Involving women at each stage of policy and decision making process to make their voices heard & 2.49 & 0.696 \\
Introduction of modern farm inputs & 2.76 & 0.512 \\
Diversification of farming enterprises & 2.75 & 0.518 \\
\hline
\end{tabular}

\section{Conclusion}

Based on the findings of the study, the following conclusions were drawn

1. Women perceived that family inheritance, communal inheritance, land lease, land purchase and gift land were the land ownership structures existing in all the communities.

2. The land ownership pattern of women in all the communities was that majority of women own land in their husband's name.

3. Although women had high access to farm land for agricultural purposes such as individual land, family land,communal land and gift land, but the conditions for women access to such farm land included: involvement of husband, through male relative, provide material like wine, kola nut and pay land rate

4. Women use land for the following agricultural purposes: backyard farming, poultry house and vegetable production.

5. Women farmers' constraints to access and use of land for agricultural purposes were: cultural barrier, present land ownership structure, lack of collateral and high level of poverty.

6. Perceived effective strategies to improve access and use of land by women included: promotion of women's participation in land matters, economic empowerment of women and use of women pressure groups to state their case.

\section{Recommendations}

The study recommends the following:

(1.) Local government councils should grant land use rights to women in rural communities to improve their access 
and use of land for agricultural purposes.

(2.) Group formation and membership should be promoted and encouraged to enhance women purchasing power through access to credit, and common voice in accessing communal lands.

(3.) Extension Agency should create programmes that will enhance the level of education of rural women to enable them contribute more in agricultural enterprise.

\section{References}

Adinya, Ibom, Ayake, Agopu, Umoh, Umeh ( 2008 ). Analysis of selected variables affecting small scale pig production in Cross River state, Nigeria.Continental journal of Agricultural Economics vol 2, pp52-57.

Aluko, B. T. \& Amidu, A. (2006). Women and Land Rights Reforms in Nigeria. Paper Presented at $5^{\text {th }}$ FIG Regional Conference in Promoting Land Administration and Good Governance. Accra, March, 8-11

British Council Nigeria (2012). Gender in Nigeria report: Improving the lives of girls and women in Nigeria. Issues, Policies, Action $2^{\text {nd }}$ edition

Ekesionye E.N and Okolo, A.N (2012) women empowerment and participation in economic activities.indisposable tools for self reliance and development of Nigerian society. Educational research and review.vol.( 1 )pp 10 -18 available online at http://www.academic journal .org/ ERR.(11)

FAO (2013).Improving the relevance and effectiveness of agricultural extension activities. FAO

Corporate Document Repository. Produced by: Natural Resources Managementand Environment Department www.fao.org/dorep/V4805E/v4805e05.htm Downloaded 19th April, 2013

Ikeduru NG ( 2002) . Women entrepreneurship and development, The gendering of microfinance in

Nigeria. A paper presented at the $8^{\text {th }}$ international interdisciplinary congress on women, $21-26$ July , 2002, maker ere university, Kampala, Uganda.

Odurukwe, S. N., Matthews-Njoku E. C. and Ejiogu-Okereke, N. (2006).Impacts of the women-in-agriculture (WIA) extension programme on women's lives; implications for subsistence agricultural production of women in Imo State, Nigeria. Livestock Research for Rural Development 18 (2), 47-61

National population commission 2006, land mass compiled from NPC Report, 1991 and field Reports.http://macosconsultancy.com/Lists\%20of\%20Nigerian\%20State\%20by\%20Landma .ss\%20and\%20Population\%20Densityyy.html

Nizioki A. ( 2002), towards women's equal rights to land in eastern Africa. East Africa Sub-Regional Support Initiative for the Advancement of Women (EASSI), Kampala.

Nwadiaro, E. C. C. and Okoroafor (2011).Gender roles and access to material and economic resources in Nigerian rural communities. Research Journal of International Studies- Issue 18; 26-33

Rahman, S.A (2004) gender differential in labour contribution and productivity in farm production empirical evidence from Kaduna state of Nigeria. Paper presented at the national conference on family held at new thearetre complex, benue state university, makurdi Nigeria $1^{\text {st }}-5^{\text {th }}$ march 2004.

Ugwu, T.(2000) inhabitionary religious practices against women in igbo society. A paper presented to women at workshop, oct $.16^{\text {th }}$ 2000 university of Nigeria nsukka.

World Bank (2009).An assessment of the investment climate in Nigeria. The World Bank, Washington 